\title{
PENGGUNAAN METODE ANALISIS KOMPONEN UTAMA UNTUK MEREDUKSI FAKTOR-FAKTOR INFLASI DI KOTA AMBON
}

\author{
M. S. Noya Van Delsen ${ }^{1}$, A. Z. Wattimena ${ }^{2}$, S. D. Saputri ${ }^{3}$ \\ 1,2,3 Jurusan Matematika FMIPA, Universitas Pattimura \\ Jl. Ir. M. Putuhena, Kampus Unpatti, Poka, Ambon, Indonesia \\ e-mail: ${ }^{1}$ marlonvd@gmail.com; ${ }^{3}$ Susantri_saputri@yahoo.com;
}

\begin{abstract}
Abstrak.
Principal Component Analysis (PCA) merupakan suatu teknik statistik untuk mengubah dari sebagian besar variabel asli yang digunakan dan saling berkorelasi satu dengan yang lainnya, menjadi satu set variabel baru yang lebih kecil dan saling bebas (tidak berkorelasi lagi). Penelitian ini bertujuan untuk mengetahui faktor-faktor yang mempengaruhi inflasi di Kota Ambon dengan mernggunakan analisis komponen utama. Variabel yang digunakan dalam penelitian ini ada 10 variabel, yaitu Bahan makanan $\left(X_{1}\right)$, Makanana jadi, minuman, tembakau, rokok $\left(X_{2}\right)$, Perumahan, air, listrik, gas, bahan bakar $\left(X_{3}\right)$, Sandang $\left(\mathrm{X}_{4}\right)$, Kesehatan $\left(X_{5}\right)$, Pendidikan, rekreasi, olahraga $\left(X_{6}\right)$, Transportasi, komunikasi, dan jasa keuangan $\left(X_{7}\right)$, Nilai Tukar $\left(X_{8}\right)$, Ekspor $\left(X_{9}\right)$ dan Impor $\left(X_{10}\right)$. Berdasarkan hasil penelitian terlihat dari 10 (sepuluh) variabel, yang terbentuk menjadi satu faktor utama yang mempengaruhi Inflasi di Kota Ambon, yaitu faktor Kebutuhan Ekonomi dengan total varian (comulative percent of variance) sebesar 77, $778 \%$.
\end{abstract}

Kata Kunci : Analisis Komponen Utama (AKU), Inflasi

\section{THE USEFULL OF MAIN COMPONENT ANALYSIS METHOD TO REDUCE INFLATION FACTORS IN AMBON CITY}

\begin{abstract}
This study aims to determine the extent to which factors affect inflation in the city of Ambon by using the Main Component Analysis. This research was conducted at the Central Bureau of Statistics of Maluku Province. Researchers obtained data by conducting direct interviews with resource persons and retrieving data directly from the Central Bureau of Statistics of Maluku Province, as well as taking data from the relevant literature of literature and books related to the problem. Causes Inflation in Indonesia is mostly influenced by non-monetary factors such as the increase of fuel oil (BBM) and the increase of basic electricity tariff (TDL), while the main factor in Ambon City is influenced by several factors such as food, beverages, tobacco, cigarettes, housing, water, electricity, fuel, health, education, recreation, sports, transportation, communications and financial services, farmer exchange, export and import. This circumstance causes the substitution of replacement goods to be limited or even absent so that prices rise. Based on the discussion on Main Component Analysis to reduce Inflation factors in Ambon City, from ten variables, there are seven variables of reduction result into one main factor affecting Inflation in Ambon City, namely Economic Needs factor with total variance (comulative parcent of variance) of $77,788 \%$.
\end{abstract}

Keywords: Inflation, Main Component Analysis (AKU).

\section{Pendahuluan}

Penyebab inflasi di Indonesia lebih banyak dipengaruhi oleh faktor non-moneter seperti kenaikan bahan bakar minyak (BBM) dan kenaikan tarif dasar listrik (TDL). Sedangkan faktor-faktor inflasi secara umum pada suatu daerah adalah meningkatnya kegiatan ekonomi, kenaikan biaya produksi, tingkat pengeluaran, nilai tukar petani, tingginya indeks harga konsumen (IHK), kenaikan upah dari pekerja dan keamanan politik ekonomi. Hal ini yang menyebabkan faktor produksi dan penyediaan barang menjadi 
turun, sementara faktor-faktor utama di Kota Ambon dipengaruhi oleh beberapa faktor diantaranya adalah bahan makanan, makanan jadi, minuman, tembakau, rokok, perumahan, air, gas, listrik, bahan bakar, sandang, kesehatan, pendidikan, rekreasi, olahraga, transportasi, komunikasi, dan jasa keuangan, nilai tukar petani, ekspor dan impor [1]. Keadaan ini yang menyebabkan subtitusi barang pengganti terbatas atau bahkan tidak ada, sehingga harga-harga menjadi naik.

Untuk mengatasi masalah tersebut dapat dilakukan dengan cara mereduksi faktor-faktor yang mempengaruhi inflasi. Salah satu metode yang akan digunakan untuk mengatasi masalah tersebut adalah metode Analisis Komponen Utama (AKU). Analisis Komponen Utama merupakan Analisis dalam ilmu ststistika yang bertujuan untuk mereduksi dimensi suatu data tanpa mengurangi karakteristik data tersebut secara signifikan. Selain untuk mereduksi faktor-faktor, Analisis Komponen Utama juga dapat digunakan untuk mengatasi masalah multikolinieritas dalam Analisis Regresi Linier Berganda. Hingga kini Analisis Komponen Utama masih terus dikembangkan untuk mereduksi faktor-faktor. Salah satunya, penelitian [2] yang menggunakan Analisis Komponen Utama untuk mengatasi penyakit jantung koroner.

\section{Tinjauan Pustaka dan Landasan Teori}

\subsection{Tinjauan Pustaka}

Metode Principal Component Analysis (PCA) ditemukan oleh Karl Pearson pada tahun 1901 yang digunakan pada bidang biologi. Pada tahun 1947 teori ini ditemukan kembali oleh Karhunen, dan kemudian dikembangkan oleh Loeve pada tahun 1963, sehingga teori ini juga dinamakan Karhunen-Loeve transform pada bidang ilmu telekomunikasi. Principal component analysis (PCA) merupakan suatu teknik statistik untuk mengubah dari sebagian besar variabel asli yang digunakan yang saling berkorelasi satu dengan yang lainnya menjadi satu set variabel baru yang lebih kecil dan saling bebas. Jadi principal component analysis (PCA) berguna untuk mereduksi data, sehingga lebih mudah untuk menginterpretasikan data-data tersebut[3].

Tahun 2011, pada penelitian [4] yang berjudul "Perbandingan Reduksi Data Menggunakan Transformasi Cosinus Diskrit dan Analisa Komponen Utama (AKU)” Program Studi Teknik Informatika Sekolah Tinggi Informatika dan Komputer Indonesia Malang. Dalam penelitian ini membahas bahwa ada metode Diskrit Cosinus Transforms (DCT) untuk reduksi dimensi data menggantikan metode Principal Component Analysis (PCA).

Tahun 2016, pada penelitian [5] yang berjudul "Perbandingan Regresi Ridge dan Principal Component Analysis dalam Mengatasi Multikolinearitas” Dosen pada Jurusan Matematika Fakultas Sains dan Teknologi Universitas Istana Negeri Makassar. Membahas tentang metode ridge lebih baik dari Principal Component Analysis (PCA) karena nilai MSE yang diteliti untuk regresi ridge minimum dan nilai $R^{2}$ besar.

\subsection{Landasan Teori}

\subsubsection{Analisis komponen utama}

Analisis Komponen Utama biasanya digunakan untuk [6]:

1. Identifikasi variabel baru yang mendasari data variabel ganda.

2. Mengurangi banyaknya dimensi himpunan variabel yang biasanya terdiriatas variabel yang banyak dan saling berkolerasi dengan mempertahankan sebanyak mungkin keragaman dalam himpunan data tersebut.

3. Menghilangkan variabel-variabel asal yang mempunyai sumbangan informasi yang relatif kecil variabel baru yang dimaksud di atas disebut komponen utama yang mempunyai ciri yaitu :

a. Merupakan kombinasi linier variabel-variabel asal.

b. Jumlah kuadrat koefisien dalam kombinasi linier tersebut berrnilai satu.

c. Tidak berkorelasi, dan mempunyai ragam berurut dari yang terbesar ke yang terkecil.

Bila pendekatan pearson dapat dikaitkan dengan masalah ruang vektor, yaitu mencari ruang vektor optimum. pendekatan Hotelling dapat dikaitkan dengan masalah variabel acak, yaitu variabel acak baru yang tertata keragamannya dan tidak berkorelasi, maka pendekatan lainnya ialah dari sisi komputasi. 
Analisis komponen utama digunakan untuk menjelaskan struktur matriks varians-kovarians dari suatu set variabel melalui kombinasi linier dari variabel-variabel tersebut. Secara umum komponen utama dapat digunakan untuk mereduksi dan menginterpretasi variabel-variabel. Misalkan saja terdapat $p$ buah variabel yang terdiri atas $n$ buah objek. Misalkan pula bahwa dari $p$ buah variabel tersebut dibuat sebanyak $k$ buah komponen utama (dengan $k \leq p$ ) yang merupakan kombinasi linier atas $p$ buah variabel tersebut. $K$ komponen utama tersebut, dapat menggantikan $p$ buah variabel yang membentuknya tanpa kehilangan banyak informasi mengenai keseluruhan variabel. Umumnya analisis komponen utama merupakan (analisis intermediate/analisis antara) yang berarti hasil komponen utama dapat digunakan untuk analisis selanjutnya [7].

\subsubsection{Menghitung Barlett Test of Sphericity dan nilai Keiser-Meyers-Oklin (KMO)}

Sebelum melakukan Proses analisis komponen utama didasarkan pada sebuah matriks korelasi. Langkah awal yang dilakukan dalam analisis komponen utama adalah pembentukan matriks korelasi. Matriks ini digunakan untuk mendapatkan nilai kedekatan hubungan antar variabel penelitian. Nilai kedekatan ini dapat digunakan untuk melakukan beberapa pengujian untuk melihat kesesuaian dengan nilai korelasi yang diperoleh dari analisis komponen utama [8].

\section{a. Uji Bartlett}

Pengujian dengan uji Bartlet digunakan untuk melihat apakah matriks korelasinya merupakan matriks identitas. Uji ini digunakan apabila sebagian besar koefisien korelasinya kurang dari 0,5.

Hipotesis :

$H_{0} \quad$ : matriks korelasi merupakan matriks identitas

$H_{1} \quad$ : matriks korelasi bukan matriks identitas

Statistik uji :

dimana :

$$
x_{o b s}^{2}=-\left[(N-1)-\frac{(2 p+5)}{6}\right] \ln |R|
$$

$$
\begin{aligned}
N & =\text { jumlah observasi } \\
p & =\text { jumlah variabel } \\
|R| & =\text { determinan matriks korelasi }
\end{aligned}
$$

Keputusan :

$$
\begin{aligned}
& H_{0}: \text { diterima jika } x_{o b s}^{2}<x_{\sigma . p(p-1) / 2}^{2} \\
& H_{0}: \text { ditolak jika } x_{o b s}^{2} \geq x_{\sigma . p(p-1) / 2}^{2}
\end{aligned}
$$

Tahap selanjutnya adalah melakukan uji Bartlett test of spericity yang dipakai untuk menguji korelasi antar variabel-variabel dalam sampel. Pengujian untuk melihat apakah data yang diperoleh layak digunakan untuk diolah yaitu dengan melihat nilai Keiser Meyer Olkin (KMO) dan Measure Of Sampling Adequancy (MSA). Analisis faktor dianggap layak digunakan apabila besaran KMO > 0,5 dan MSA yang digunakan untuk mengukur derajat korelasi antar variabel dengan kriteria MSA > 0,6. [6]

\section{b. Uji Kaiser Meyer Olkin (KMO)}

Uji ini digunakan untuk mengetahui apakah data observasi tersebut layak dan dapat dianalisis dengan analis komponen utama [9]. Nilai statistik Kaiser Meyer Olkin (KMO) digunakan untuk mengukur kecukupan samplingnya, dengan rumus :

$$
K M O=\frac{\sum_{i \neq j} r_{i j}^{2}}{\sum \sum_{i \neq j} r_{i j}^{2}+\sum \sum_{i \neq j} a_{i j}^{2}}, i=1,2, \cdots, p ; j=1,2, \cdots, p
$$

dimana :

$$
\begin{aligned}
& r_{i j}=\text { koefisien korelasi sederhana antara variabel ke- } i \text { dan ke- } j \\
& a_{i j}=\text { koefisien korelasi parsial antara variabel ke- } i \text { dan ke- } j
\end{aligned}
$$


Jika nilai koefisien korelasi parsial adalah kecil dibandingkan dengan koefisien korelasi, maka nilai KMO akan mendekati 1. Nilai KMO yang kecil mengindikasikan bahwa penggunaan analisis faktor harus dipertimbangkan kembali, karena korelasi antara variabel tidak dapat diterangkan oleh variabel lain. Adapun kriteria keputusannya adalah sebagai berikut [10] :

Tabel 1. Kriteria Keputusan

\begin{tabular}{|c|l|}
\hline Nilai KMO & $\begin{array}{c}\text { Interpretasi } \\
\text { (Analisis Faktor) }\end{array}$ \\
\hline $0.90-1.00$ & Data sangat baik \\
\hline $0.80-0.90$ & Data baik \\
\hline $0.70-0.80$ & Data agak cukup \\
\hline $0.60-0.70$ & Data lebih dari cukup \\
\hline $0.50-0.60$ & Data cukup \\
\hline $0.00-0.50$ & Data tidak layak \\
\hline
\end{tabular}

\subsubsection{Penentuan Faktor Componen Berdasarkan Nilai Eigen Value}

Nilai Eigen value merupakan suatu nilai yang menunjukkan seberapa besar pengaruh suatu variabel terhadap pembentukan karakteristik yang dinotasikan dengan $\lambda$. Mengekstraksi Faktor atau Extracting Factors yaitu metode yang umum digunakan untuk melihat eigen value lebih besar atau sama dengan 1 atau 0 dan melihat diagram scarter. Faktor penentuan berdasarkan nilai eigen value lebih besar dari 1 dipertahankan, tetapi jika lebih kecil dari 1 maka faktornya dikeluarkan dalam model. Suatu eigen value menunjukan besar sumbangan dari faktor terhadap varian seluruh variabel asli. Hanya faktor dengan varian lebih dari 1 dimasukan dalam model. Faktor dengan varian kurang dari 1 tidak baik karena variabel asli telah dibakukan yang berarti rata-ratanya 0 dan variansinya $1 .[11]$

\subsubsection{Penentuan Analisis Komponen Utama (AKU)}

Ada tiga cara yang digunakan untuk jumlah komponen utama (principal component) yang akan digunakan untuk analisa selanjutnya, pertama dengan melihat nilai variansi yang dapat dijelaskan lebih dari $80 \%$. Cara kedua adalah dengan melihat nilai eigen yang lebih dari satu. Cara ketiga adalah dengan mengamati scree plot yaitu dengan melihat patahan siku dari dari scree plot. Pada penelitian ini untuk menetukan jumlah komponen utama yang dihasilkan pada Analisis Komponen Utama (AKU) adalah dengan melihat nilai eigen lebih dari satu.

\section{Hasil dan Pembahasan}

Pada penelitian ini data yang digunakan adalah data sekunder. Cakupan data yang digunakan dalam penelitian ini adalah data pada tahun 2016. Data diperoleh dari BPS (Badan Pusat Statistik) melalui catatan atau arsip yang dibuat dan dipublikasikan oleh lembaga-lembaga terkait dengan penelitian ini melalui media informasi berbasis internet, dan akan diolah dengan software SPSS. Dimana variabel yang digunakan dalam penelitian ini ada 10 variabel, yaitu Bahan makanan $\left(X_{1}\right)$, Makanana jadi, minuman, tembakau, rokok $\left(X_{2}\right)$, Perumahan, air, listrik, gas, bahan bakar $\left(X_{3}\right)$, Sandang $\left(X_{4}\right)$, Kesehatan $\left(X_{5}\right)$, Pendidikan, rekreasi, olahraga $\left(X_{6}\right)$, Transportasi, komunikasi, dan jasa keuangan $\left(X_{7}\right)$, Nilai Tukar $\left(X_{8}\right)$, Ekspor $\left(X_{9}\right)$, Impor $\left(X_{10}\right)$. Pada penelitian kali ini digunakan 10 faktor-faktor yang mempengaruhi terjadinya inflasi di Kota Ambon.

Tabel 2 di bawah menunjukan data pada tahun 2016 yang diperoleh dari BPS (Badan Pusat Statistik) melalui catatan atau arsip yang dibuat dan dipublikasikan oleh lembaga-lembaga terkait [12]. Berikut data penelitiannya: 
Tabel 2. Data Penelitian (\%)

\begin{tabular}{|r|r|r|r|r|r|r|r|r|r|r|}
\hline No & \multicolumn{1}{|c|}{$X_{1}$} & \multicolumn{1}{|c|}{$X_{2}$} & \multicolumn{1}{|c|}{$X_{3}$} & $X_{4}$ & \multicolumn{1}{|c}{$X_{5}$} & \multicolumn{1}{c|}{$X_{6}$} & \multicolumn{1}{c|}{$X_{7}$} & \multicolumn{1}{c|}{$X_{8}$} & \multicolumn{1}{c|}{$X_{9}$} & $X_{10}$ \\
\hline 1. & 126,19 & 110,43 & 116,84 & 113,82 & 112,97 & 124,52 & 136,58 & 103.55 & 30 & 108,49 \\
\hline 2. & 130,28 & 110,89 & 116,64 & 113,93 & 113,95 & 124,09 & 133,56 & 103.83 & 94,32 & 88,58 \\
\hline 3. & 128,64 & 111,1 & 116,7 & 114,10 & 113,59 & 123,85 & 132,91 & 103.9 & 101,02 & 224 \\
\hline 4. & 122,97 & 111,4 & 116,68 & 114,31 & 113,09 & 123,91 & 132,19 & 103.96 & 0 & 17,41 \\
\hline 5. & 124,35 & 112,7 & 116,83 & 115,3 & 113,89 & 124,37 & 139,03 & 103.5 & 20,81 & 0 \\
\hline 6. & 123,62 & 113,7 & 117,23 & 116,23 & 114,13 & 124,71 & 139,68 & 103.01 & 34,69 & 436,19 \\
\hline 7. & 123,71 & 113,78 & 117,74 & 116,79 & 114,97 & 124,74 & 141,37 & 103.34 & 171,49 & 199,42 \\
\hline 8. & 132,47 & 113,67 & 117,83 & 117,17 & 115,12 & 124,73 & 134,24 & 102.28 & 1,86 & 148,99 \\
\hline 9. & 130,18 & 113,56 & 117,96 & 117,66 & 115,35 & 135,16 & 135,66 & 101.52 & 2,05 & 149,77 \\
\hline 10. & 129,64 & 113,88 & 118,23 & 117,76 & 115,58 & 135,16 & 135,78 & 100.93 & 17,93 & 276,33 \\
\hline 11. & 132,67 & 114,42 & 118,4 & 117,7 & 115,66 & 134,6 & 135,1 & 100.83 & 0 & 202,31 \\
\hline 12. & 130,10 & 115,45 & 118,44 & 118,77 & 115,3 & 134,58 & 140,6 & 100.67 & 21,32 & 216,82 \\
\hline
\end{tabular}

Selanjutnya akan dilakukan uji statistik deskriptif yaitu sebagai berikut :

Tabel 3. Hasil Uji Deskriptif Statistik

\begin{tabular}{|l|c|r|r|}
\hline & Mean & Std. Deviation & Analysis N \\
\hline$\times 1$ & $1.2790 \mathrm{E} 2$ & 3.54993 & 12 \\
$\times 2$ & $1.1292 \mathrm{E} 2$ & 1.59215 & 12 \\
$\times 3$ & $1.1746 \mathrm{E} 2$ & .71317 & 12 \\
$\times 4$ & $1.1604 \mathrm{E} 2$ & 1.64967 & 12 \\
$\times 5$ & $1.1454 \mathrm{E} 2$ & .88931 & 12 \\
$X 6$ & $1.2698 \mathrm{E} 2$ & 4.71277 & 12 \\
$\times 7$ & $1.3639 \mathrm{E} 2$ & 3.09406 & 12 \\
$\times 8$ & $1.0261 \mathrm{E} 2$ & 1.29316 & 12 \\
$\times 9$ & 41.2908 & 53.40333 & 12 \\
$\times 10$ & $1.7236 \mathrm{E} 2$ & 117.76751 & 12 \\
\hline
\end{tabular}

Sumber : Hasil penelitian (output SPSS)

Statistika deskriptif ialah variabel yang mempengaruhi inflasi. Dilihat dari Tabel 3 rata-rata tertinggi dari variabel yang didefenisikan adalah variabel ekspor $\left(X_{9}\right)$ sebesar 41,2908.

Selanjutnya akan dilakukan uji Bartlett dan uji Kaiser Meyer Olkin (KMO). Berikut hasil uji Bartlett dan uji Kaiser Meyer Olkin (KMO) :

Tabel 4. KMO dan Bartlett Test

\begin{tabular}{|l|r|}
\hline $\begin{array}{l}\text { Kaiser-Meyer-Olkin Measure of Sampling } \\
\text { Adequacy. }\end{array}$ & 0,571 \\
\hline Bartlett's Test of Sphericity Approx. ChiSquare & 118,434 \\
\hline Df & 45 \\
\hline Sig. & 0,000 \\
\hline
\end{tabular}

Hasil perhitungan dengan SPSS dihasilkan nilai Barlett Test of Spehricity sebesar 118,434 dengan signifikansi sebesar 0,000. Dengan demikian Bartlett Test of Spehricity memenuhi persyaratan karena signifikansi di bawah 0,05 (5\%). Sedangkan pada tabel KMO and Bartlett's test, terlihat angka K-M-O Measure of Sampling Adequacy (MSA) adalah 0,571. Oleh karena angka MSA di atas 0,5, maka kumpulan variabel tersebut dapat diproses lebih lanjut. Selanjutnya tiap variabel dianalisis untuk mengetahui mana yang dapat diproses lebih lanjut dan mana yang harus dikeluarkan. Setelah dilakukan uji Bartlett dan uji Kaiser Meyer Olkin (KMO), berikutnya akan dilakukan uji MSA (Measure of Sampling Adequacy). Berikut hasil ujinya : 
Tabel 5. MSA (Measure of Sampling Adequacy) Anti-image Matrices

\begin{tabular}{|c|c|c|c|c|c|c|c|c|c|c|c|}
\hline & & $x_{1}$ & $\times 2$ & $\times 3$ & $X_{4}$ & $\times 5$ & $x_{6}$ & $x_{7}$ & $x_{8}$ & $\times 9$ & $\times 10$ \\
\hline \multirow[t]{10}{*}{ Anti-image Covariance } & $x 1$ & .157 & -.032 & .003 & .001 & .015 & .051 & .058 & .032 & -.070 & .081 \\
\hline & $\times 2$ & -.032 & .034 & -.002 & -.001 & -.010 & -.018 & -.030 & -.010 & .031 & -.045 \\
\hline & $\times 3$ & .003 & -.002 & .021 & -.007 & .004 & -.008 & .007 & .007 & -.020 & .025 \\
\hline & $\times 4$ & .001 & -.001 & -.007 & .008 & -.008 & .016 & -.010 & .001 & .012 & -.025 \\
\hline & $\times 5$ & .015 & -.010 & .004 & -.008 & .013 & -.008 & .023 & .003 & -.025 & .045 \\
\hline & $x_{6}$ & .051 & -.018 & -.008 & .016 & -.008 & .079 & .003 & .022 & -.012 & -.011 \\
\hline & $x 7$ & .058 & -.030 & .007 & -.010 & .023 & .003 & .053 & .012 & -.057 & .085 \\
\hline & $x_{8}$ & .032 & -.010 & .007 & .001 & .003 & .022 & .012 & .013 & -.023 & .023 \\
\hline & $\times 9$ & -.070 & .031 & -.020 & .012 & -.025 & -.012 & -.057 & -.023 & .084 & -.113 \\
\hline & $\times 10$ & .081 & -.045 & .025 & -.025 & .045 & -.011 & .085 & .023 & -.113 & .271 \\
\hline \multirow[t]{10}{*}{ Anti-image Correlation } & $x 1$ & $.473^{2}$ & -.438 & .054 & .040 & .333 & .455 & .630 & .705 & -.608 & .395 \\
\hline & $\times 2$ & -.438 & $.700^{\circ}$ & -.061 & -.089 & -.477 & -.348 & -.697 & -.471 & .575 & -.470 \\
\hline & $\times 3$ & .054 & -.061 & $.836^{2}$ & -.514 & .257 & -.198 & .211 & .424 & -.474 & .328 \\
\hline & $\times 4$ & .040 & -.089 & -.514 & $.695^{a}$ & -.747 & .646 & -.471 & .123 & .460 & -.544 \\
\hline & $\times 5$ & .333 & -.477 & .257 & -.747 & $.583^{2}$ & -.238 & .858 & .232 & -.764 & .760 \\
\hline & $X_{6}$ & .455 & -.348 & -.198 & .646 & -.238 & $.708^{a}$ & .046 & .666 & -.142 & -.078 \\
\hline & $x 7$ & .630 & -.697 & .211 & -.471 & .858 & .046 & $.235^{\beth}$ & .458 & -.847 & .704 \\
\hline & $x 8$ & .705 & -.471 & .424 & .123 & .232 & .666 & .458 & $.674^{a}$ & -.693 & .380 \\
\hline & $\times 9$ & -.608 & .575 & -.474 & .460 & -.764 & -.142 & -.847 & -.693 & $.174^{2}$ & -.751 \\
\hline & $\times 10$ & .395 & -.470 & .328 & -.544 & .760 & -.078 & .704 & .380 & -.751 & $.288^{2}$ \\
\hline
\end{tabular}

a. Measures of Sampling Adequacy(MSA)

Pada Tabel 5 hasil analisis awal menunjukan nilai MSA (Measure of Sampling Adequacy) untuk variabel- variabel yang diteliti. Nilai MSA pada tabel di atas ditunjukkan pada baris Anti Image Correlation dengan tanda “a”. Dari Tabel 5 di atas, dapat dilihat bahwa ada nilai MSA yang $<0,5$ yaitu ada pada $X_{1}$ dengan nilai MSA $=0,473$ dimana $<0,5$ maka $X_{1}$ tidak memenuhi syarat MSA, MSA $X_{7}=0,235<0,5 X_{7}$ tidak memenuhi syarat MSA berlaku juga pada $X_{9}$ dengan nilai MSA $X_{9}=0,174$ dan $X_{10}$ dengan nilai MSA $X_{10}<0$,5. Dari 10 variabel, ada 4 variabel dengan MSA $<0,5$, maka 4 variabel dikeluarkan dari pengujian. Sehingga harus mengulangi pengujian tanpa mengikut sertakan ke-4 variabel diatas $\left(X_{1}, X_{7}, X_{9}, X_{10}\right)$. Karena ada 4 variabel yang tidak memenuhi syarat nilai MSA maka pengulangan pengujian dilakukan 4 (empat) kali dengan mengeluarkan satu-satu variabel. Pertama akan dikeluarkan $X_{1}$ kemudian $X_{7}$, dan $X_{9}$ tapi pada saat dikeluarkannya $X_{9}$ nilai MSA pada $X_{10}$ sudah berubah menjadi 0,757 $>0,5$ maka $X_{10}$ memenuhi syarat MSA. Sehingga pengujian ulang hanya dilakukan 3 (tiga) kali saja untuk mendapatkan nilai MSA untuk semua variabel > 0,5 agar memenuhi syarat nilai MSA. Pengujian ulang untuk nilai MSA ini juga mengubah nilai KMO dan Bartlett dapat dilihat pada Tabel 6.

Tabel 6. ( Output KMO dan Bartlett Test)

\begin{tabular}{|l|r|}
\hline $\begin{array}{l}\text { Kaiser-Meyer-Olkin Measure of Sampling } \\
\text { Adequacy. }\end{array}$ & 0,750 \\
\hline Bartlett's Test of Sphericity Approx. Chi-Square & 93,058 \\
\hline Df & 21 \\
\hline Sig. & 0,000 \\
\hline
\end{tabular}

Sumber : Hasil penelitian (Output SPSS)

Pada analisis ulang untuk nilai MSA maka nilai KMO dan Bartlett Test berubah menjadi 0,750 dari nilai semula 0,571 . 
Tabel 7. Output MSA (Measure of Sampling Adequacy)

Anti-image Matrices

\begin{tabular}{|c|c|c|c|c|c|c|c|c|}
\hline & & $\times 2$ & $\times 3$ & $\times 4$ & $\times 5$ & $\times 6$ & $X_{8}$ & $\times 10$ \\
\hline \multirow[t]{7}{*}{ Anti-image Covariance } & $\times 2$ & .066 & .006 & -.024 & .027 & -.047 & -.026 & .005 \\
\hline & $\times 3$ & .006 & .035 & -.010 & -.003 & -.021 & .010 & -.002 \\
\hline & $X_{4}$ & -.024 & -.010 & .014 & -.021 & .030 & .014 & -.026 \\
\hline & $\times 5$ & .027 & -.003 & -.021 & .073 & -.037 & -.021 & .084 \\
\hline & $x_{6}$ & -.047 & -.021 & .030 & -.037 & .115 & .054 & -.055 \\
\hline & $x_{8}$ & -.026 & .010 & .014 & -.021 & .054 & .049 & -.032 \\
\hline & $\times 10$ & .005 & -.002 & -.026 & .084 & -.055 & -.032 & .666 \\
\hline \multirow[t]{7}{*}{ Anti-image Correlation } & $\mathrm{X} 2$ & $.749^{2}$ & .123 & -.776 & .389 & -.537 & -.454 & .025 \\
\hline & $\times 3$ & .123 & $.918^{\mathrm{a}}$ & -.444 & -.066 & -.323 & .244 & -.014 \\
\hline & $x_{4}$ & -.776 & -.444 & $.663^{\mathrm{a}}$ & -.647 & .728 & .524 & -.264 \\
\hline & $x_{5}$ & .389 & -.066 & -.647 & $.790^{\mathrm{a}}$ & -.409 & -.347 & .381 \\
\hline & $X_{6}$ & -.537 & -.323 & .728 & -.409 & $.631^{2}$ & .710 & -200 \\
\hline & $x_{8}$ & -.454 & .244 & .524 & -.347 & .710 & $.769^{2}$ & -175 \\
\hline & $\times 10$ & .025 & -.014 & -.264 & .381 & -.200 & -.175 & $.757^{\mathrm{a}}$ \\
\hline
\end{tabular}

a. Measures of Sampling Adequacy(MSA)

Sumber : Hasil penelitian (Output SPSS)

Berdasarkan Tabel 7, menunjukkan bahwa 7 (tujuh) variabel diuji memenuhi persyaratan MSA yaitu di atas 0,5 sehingga dapat digunakan untuk pengujian selanjutnya.

\subsection{Komunalitas}

Tabel 8. Output Komunalitas

\begin{tabular}{|c|c|c|}
\hline & Initial & Extraction \\
\hline $\mathrm{X}_{2}$ & 1,000 & 0,869 \\
\hline $\mathrm{X}_{3}$ & 1,000 & 0,964 \\
\hline $\mathrm{X}_{4}$ & 1,000 & 0,934 \\
\hline $\mathrm{X}_{5}$ & 1,000 & 0,870 \\
\hline $\mathrm{X}_{6}$ & 1,000 & 0,668 \\
\hline $\mathrm{X}_{8}$ & 1,000 & 0,909 \\
\hline $\mathrm{X}_{10}$ & 1,000 & 0,232 \\
\hline
\end{tabular}

Extraction Method: Principal Component Analysis

Sumber : Hasil penelitian (Output SPSS)

Berdasarkan Tabel 8, Pada kolom Initial terlihat nilai communalities untuk setiap variabel masingmasing 1 (satu). Angka ini terlihat didalam diagonal matriks korelasi. Sedangkan pada kolom Extraction menunjukan seberapa besar faktor yang terbentuk dapat menerangkan varian suatu variabel. Angka pada kolom ini selalu bernilai positif. Nilai communalities tertinggi adalah variabel $X_{3}$ sebesar 0,964 artinya faktor perumahan, air, gas, listrik, dan bahan bakar dapat menjelaskan 96.9\% varians faktor yang terbentuk. Sebaliknya nilai communalities yang terendah adalah variabel $X_{10}$ sebesar 0,232 artinya faktor impor dapat menjelaskan 23, \% varians faktor yang terbentuk. Demikian dengan variabel-variabel yang lainnya. Semua variabel dapat dijelaskan oleh faktor yang terbentuk dengan ketentuan semakin besar communalities maka semakin erat hubungan variabel yang bersangkutan dengan faktor yang terbentuk.

\subsection{Total Varians}

Berdasarkan Tabel 9, kriteria pertama yang digunakan adalah nilai eigen dari tabel diatas diperoleh nilai eigen yang lebih besar dari 1 pada 1 faktor dengan kriteria ini diperoleh jumlah faktor yang digunakan adalah 1 faktor. Penentuan berdasarkan nilai persentase variansi total yang dapat dijelaskan oleh banyaknya faktor yang akan dibentuk. Dengan mengekstraksi variabel-variabel awal menjadi 1 faktor telah dihasilkan variansi total kumulatif sebesar 77,788\%. Jadi faktor 1 menjelaskan 77,788\% dari total variansi jika dibandingkan dengan nilai yang lain terlihat bahwa faktor 1 sangat mendominasi dalam total variansi. 
Tabel 9. ( Output Total varians)

Total Variance Explained

\begin{tabular}{|c|r|r|r|r|r|r|}
\hline \multirow{2}{*}{ Commonent } & \multicolumn{3}{|c|}{ Initial Eigenvalues } & \multicolumn{3}{c|}{ Extraction Sums of Squared Loadings } \\
\cline { 2 - 7 } & \multicolumn{1}{|c|}{ Total } & \% of Variance & Cumulative $\%$ & Total & \% of Variance & Cumulative $\%$ \\
\hline 1 & 5.445 & 77.788 & 77.788 & 5.445 & 77.788 & 77.788 \\
2 & .831 & 11.866 & 89.655 & & & \\
3 & .474 & 6.766 & 96.421 & & & \\
4 & .124 & 1.771 & 98.192 & & & \\
5 & .086 & 1.230 & 99.422 & & & \\
6 & .031 & .436 & 99.858 & & & \\
7 & .010 & .142 & 100.000 & & & \\
\hline
\end{tabular}

Extraction Method: Principal Component Analysis.

Sumber : Hasil penelitian (Output SPSS)

Nilai eigen untuk faktor 1 setelah ekstraksi pun tetap sama sebesar 77,788\%, perhatikan karena faktor yang terekstraksi hanya 1 maka rotasi tidak dapat dilakukan, sehingga SPSS tidak memunculkan kolom nilai eigen setelah rotasi. Dengan demikin ekstraksi 2 faktor yang diperoleh telah dapat dihentikan dan telah memenuhi kriteria kedua. Kriteria ketiga adalah penentuan berdasarkan scree plot. Pada Gambar 1 diketahui bahwa scree plot mulai mendatar pada ekstraksi variabel-variabel awal menjadi 1 faktor.

Scree Plot

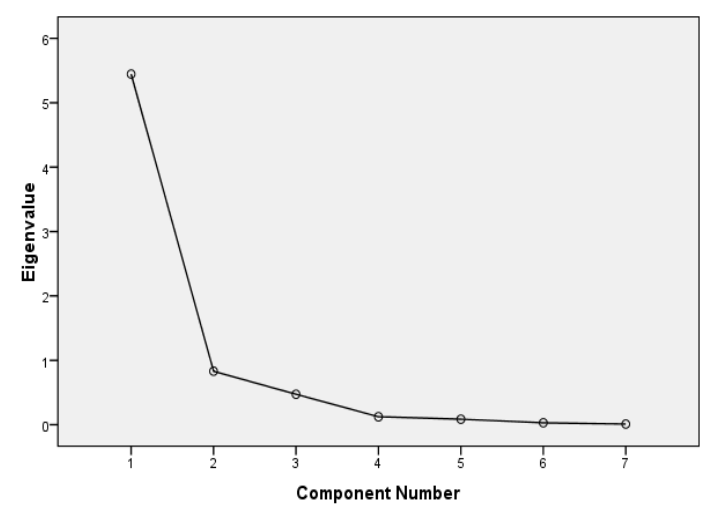

Gambar 1. Scree Plot

Sumber : Hasil penelitian (Output SPSS)

Dari kombinasi ketiga kriteria tersebut dapat disimpulkan bahwa sampel bagian kedua menghasilkan jumlah faktor sebanyak 1 faktor. Hasil yang diperoleh menunjukan bahwa hanya satu kelompok dengan faktor yang telah terbentuk pada penyederhanaan faktor-faktor yang mempengaruhi inflasi di Kota Ambon.

\subsection{Komponen Matriks}

Tabel 10. (Output Component Matriks)

\begin{tabular}{|c|c|}
\hline & Component \\
\hline & 1 \\
\hline $\mathrm{X}_{2}$ & 0.932 \\
\hline $\mathrm{X}_{3}$ & 0.982 \\
\hline $\mathrm{X}_{4}$ & 0.966 \\
\hline $\mathrm{X}_{5}$ & 0.933 \\
\hline $\mathrm{X}_{6}$ & 0.817 \\
\hline $\mathrm{X}_{8}$ & -0.953 \\
\hline $\mathrm{X}_{10}$ & 0.481 \\
\hline
\end{tabular}

Extraction Method: Principal Component Analysis Sumber : Hasil penelitian (Output SPSS) 
Dari Tabel 10, diketahui bahwa hanya satu mengekstrak 1 faktor. Menurut kriteria [10] hasil ekstraksi 1 faktor ini dikatakan akurat jika variabel yang diambil kurang dari 30 variabel, dalam kasus ini hanya 7 variabel sampel berukuran lebih dari 250 dan rata-rata communalities 0,7 atau lebih. dari interpretasi sebelumnya diketahui bahwa rata-rata communalities lebih besar dari 0,7 sehingga ekstraksi satu faktor pada analisis ini bernilai akurat. Dengan demikian kesepuluh variabel telah tereduksi menjadi 1 (satu) komponen yang disebut dengan faktor 1 terdiri atas variabel $X_{2}$ (Makanan jadi, minuman, rokok, tembakau), $X_{3}$ (perumahan, air, gas, listrik, bahan bakar), $X_{4}$ (sandang), $X_{5}$ (kesehatan), $X_{6}$ (pendidikan, rekreasi, olahraga), $X_{8}$ (nilai tukar), $X_{10}$ (impor) faktor ini dinamakan faktor Kebutuhan Ekonomi.

Berdasarkan Tabel 8, Pada kolom Initial terlihat nilai komunalitas untuk setiap variabel masingmasing 1 (satu). Angka ini terlihat didalam diagonal matriks korelasi. Sedangkan pada kolom Extraction menunjukan seberapa besar faktor yang terbentuk dapat menerangkan varian suatu variabel. Angka pada kolom ini selalu bernilai positif.

\section{Kesimpulan}

Berdasarkan hasil pembahasan mengenai penggunaan metodologi Analisis Komponen Utama untuk mereduksi faktor-faktor inflasi di Kota Ambon dari 10 variabel yang ada maka diperoleh 7 variabel hasil reduksi yaitu variabel $X_{2}$ (Makanan jadi, minuman, rokok, tembakau), $X_{3}$ (perumahan, air, gas, listrik, bahan bakar), $X_{4}$ (sandang), $X_{5}$ (kesehatan), $X_{6}$ (pendidikan, rekreasi, olahraga), $X_{8}$ (nilai tukar), $X_{10}$ (impor), menjadi 1 (satu) faktor yaitu kebutuhan ekonomi yang mempengaruhi inflasi di Kota Ambon dengan total varian (cumulative percent of variance) sebesar $77,788 \%$.

\section{Daftar Pustaka}

[1] R. Maggi \& S. D. Birgitta, “Faktor-faktor yang Mempengaruhi Inflasi di Indonesia: Model Demand Pull Inflation,” 2013.

[2] G. M. Hendro, T. B. Adji, N. A. Setiawan, "Penggunaan Metodologi Analisa Komponen Utama (PCA) untuk Mereduksi Faktor-faktor yang Mempengaruhi Penyakit Jantung.,” 2012.

[3] Johnson \& Wichern, “Applied Multivariate Statistical Analysis,” no. Edisi keenam, 2007.

[4] L. Isriyah, E. Poerbaningtyas, "Perbandingan Reduksi Data menggunakan Transformasi Cosinus Diskrit dan Analisa Komponen Utama,” 2011.

[5] Irwan \& Hasriani, "Perbandingan Regresi Ridge dan Principal Component Analysis dalam mengatasi Multikoliniaritas,” 2016.

Gourlay dan Watson, Camputational Methods for Matrix Eigenproblems, 1973.

[6] J. F. Hair, R. E. Anderson, R. I. Tatham., \& W. C. Black, "Multivariate Data Analysis With Readings," no. Edisi ke-4., 1995.

[7] R. Susetyoko \& E. Purwantini, "Teknik Reduksi Dimensi Menggunakan Komponen Utama Data Partisi Pada Pengklasifikasian Data Berdimensi Tinggi dengan Ukuran Sampel Kecil".

[8] I. T. Jolliffe, "Principal Component Analysis," vol. Edisi kedua, 2002.

[9] M. A. Supranto, "Analisis Multivariat (Arti \& Interpretasi)", Jakarta : Rineka Cipta., 2004.

[10] H. F. Kaiser, "The application of electronic computers to factor analysis. Educational and Psychological Measurement", 20, 141-151, 1960.

[11] S. Santoso, "SPSS Statistik Multivariat", Jakarta: PT. Elex Media Kompitundo, 2002.

[12] B. P. S. R. Indonesia, “www. BPS.go.id,” Badan Pusat Statistik, 2010-2013. [Online]. 
118 Noya van Delsen, dkk. | Penggunaan Metode Analisis Komponen Utama Untuk Mereduksi Faktor-Faktor ..... 